\title{
EUROPEANIZATION IN EU EXTERNAL RELATIONS AFTER THE EASTWARD ENLARGEMENT: COMPLICATIONS AND BYPASSES TO GREATER ENGAGEMENT WITH THE EASTERN ENP COUNTRIES
}

Ivan F Dumka

University of Victoria

\begin{abstract}
:
Emphasizing Poland and its relations with Ukraine, this paper applies a Europeanization framework to examine the uploading of external relations policies by EU members. It argues that as enlargement has shortened the list of countries to which the EU has made membership commitments, normative entrapment will not be at work in its external relations, nor address the more fractious nature of EU decision-making brought on by a larger and more diverse membership. This results in strategic behaviour by EU members and more laboured decision making, which can be expected, in general, to complicate the EU's external relations. Simply put, the coalition building that is so central to EU policymaking is more difficult following the eastward enlargement. However, because the new members vote, collaborate, and build coalitions in favour of closer ties to these eastern neighbours, complications from enlargement should be far less pronounced in the EU's eastern policy than with other ENP countries. This comes despite striking shortcomings by Poland in the administrative capacity and elite socialization that normally characterize those member states who often succeed at projecting their preferences onto EU policy. All of this means that one can expect an eastward shift in the focus of the EU's external relations, and a deepening of its differentiated approach to external relations.
\end{abstract}




\section{Introduction $^{1}$}

It is common to read about enlargement as an instrument of the EU's external relations, but much less so about the feedback effects that it has upon the union itself (e.g. Schimmelfennig and Wagner 2004). This is perplexing, given that changes in membership alter the interests and priorities behind the EU's external relations, and end up changing the dynamics of decisionmaking in the Union itself. Likewise, there is a growing emphasis in the academic literature upon the EU as an international actor with a distinct legal character and defined interests, and in possession of some substantial inducements for other international actors, such as access to the Single Market. If this is so, then these changes in the EU's interests and priorities, as well as how it pursues them are important indeed. Considering as well that the EU is often seen as a transformative power (Grabbe 2006), these changes in the focus of its external relations may have important implications for countries in its neighbourhood.

Problematic in this literature, however, has been an inattention to some of the subtleties and asymmetrical effects of these changing dynamics. Indeed, much of the recent literature has focused upon how enlargement fatigue and the lack of credible accession prospects for European Neighbourhood Policy (ENP) countries has limited the EU's influence abroad. Certainly, enlargement fatigue has been an important consequence of the eastern enlargement, and the resulting absence of accession prospects limits the tools available to the EU.

However, this obsession with enlargement becomes problematic when one considers that the stock of candidate countries is finite, and that the academic literature must now engage with enlargement in more circumscribed terms, i.e. in terms of the few remaining 'hopefuls', rather than as a broad field. Similarly, while the eastern enlargement has brought a distaste in the EU for further enlargement in general, differences in the mix of interests guiding its behaviour, and changed decision-making dynamics as a result of new membership can be expected to affect any future enlargement and relations with different countries unevenly, a subtlety less prominent in the current literature. Conversely, the portion of the academic literature concerned with detailed casework has been insufficiently attentive to how the eastern enlargement has affected the EU's external relations more broadly.

Moreover, while scholars of Europeanization have turned their attention to the new member states, and more recently to foreign policy, much of this work considers the domestic impact of European policy upon the new member states, rather than the reverse (e.g. Sedelmeier 2008, 2011). Indeed, while scholars are keenly aware of the ways in which enlargement has redefined the EU's immediate neighbourhood (e.g. Debardeleben 2008), less attention has been given to the new members themselves, and their role in reweighting the Union's interests concerning its near abroad. This is an important shortcoming considering that the eastward enlargement brings with it new members whose interests can potentially have important effects upon decisions made at the European level.

This paper takes up the question of the eastward enlargement, applying a Europeanization framework to examine the ways in which it has impacted the EU's external relations, with special emphasis upon the role of Poland in the EU's relations with Ukraine. This research was completed prior to November 2013, and while it focuses on events prior to the protests in Ukraine, the findings of this paper have important implications in the current context as well.

\footnotetext{
${ }^{1}$ The author would like to thank Dr. Amy Verdun for her feedback on early versions of this paper, and Graeme B. Crouch for his thoughtful and thorough advice on subsequent versions, as well the two anonymous reviewers for their helpful comments and constructive critiques.
} 
Likewise, this paper will touch upon issues with Belarus and Moldova, but Ukraine's size, economic weight, strategic importance, and, until recently, stable - if unsavoury - political system have all made for closer scrutiny, with the implication that data on the country's ties to the EU have been more forthcoming than with Belarus and Moldova. For the same reasons, closer ties to Ukraine would have larger implications for the European Union and for other countries in the EU's neighbourhood, making a study of EU-Ukraine relations more pressing than with the other two.

On the other hand, while Poland is exceptional among the Central and Eastern European Countries (CEECs) for its weight in the EU, its preferences for greater eastern engagement and the ways it pursues them are still, by most accounts, typical of the EU's new eastern membership. At the same time, Poland has been the centrepiece of collaborations with the other eastern members, as well as with older EU members on relations with the eastern ENP countries, making it the ideal window into these interactions between EU members on external relations.

This paper argues that, while along more established measures of uploading capacity, Poland and the CEECs hardly appear as 'pace-setters' in Börzel's (2002; 2003) parlance, adjustments by Polish policymakers in Brussels and administrative changes in Warsaw suggest that this may change over the longer term. More interestingly, however, it is in a less-explored area of policy uploading, namely coalition-building, that Poland and the CEECs' accession may be most consequential in the near-term. This is to say that, as enlargement has shortened the list of countries to which the EU has made strong commitments on membership, the normative entrapment and rhetorical mechanisms that so facilitated its dealings with accession countries will not address the complications that arise in the EU's decision-making with a larger and more diverse membership. Indeed, EU commitments on accession are ill-defined or absent with respect to these neighbours, even if select members such as Poland are quite supportive of their joining the EU. This results in strategic behaviour by EU members, coupled with more laboured decision-making that has come with the addition of more members, which can be expected, in general, to hinder and complicate the EU's external relations. In other words, the eastern enlargement complicates the coalition building that is so important to policy uploading.

However, Poland and these new members tend to be highly active in external relations, bringing pre-existing ties to eastern non-EU members, a strong and shared interest in deeper engagement with them, and well-established fora for collaborating to this end. This means that complications from enlargement should be far less pronounced in the EU's eastern policy than in its dealings with other ENP countries. All of this means that, while their influence over external relations has much potential to grow, so, too, can we expect to observe more dialogue, and proposals for deeper engagement with the eastern ENP countries than would otherwise be the case. In short, because of the way Poland and the CEECs have affected coalition-building and decision-making in the EU, one can expect an eastward shift in its external relations.

The paper is structured as follows: following a brief survey of the literature of Europeanization in foreign policy, it argues that while there are discernible effects upon the means by which Poland frames and pursues its foreign policy goals, EU member states retain nationally distinct preferences in external relations. Much like in other policy areas, members' success in policy uploading turns on their administrative capacity and coalition-building skills.

To that end, the paper then considers each of these factors in turn. In the second section, it examines the role of Polish administrative capacity in its attempts to upload policy to the European level, noting that this has traditionally been a hindrance to the uploading of Polish preferences, although it is improving. In the third section, it argues that a larger membership 
complicates coalition building at the European level, which in turn makes decision making in external relations more laboured in general. In the fourth section, it argues that these complications are less onerous in dealings with the EU's eastern neighbours, in particular because Poland and the CEECs share an interest in greater engagement with these countries, and because they consistently lobby, consult, vote, and build coalitions to that end, with the effect that the focus of EU decisions on external relations can be expected to shift eastward. Two sections consider in turn the empirical and theoretical implications of these findings, while a final section concludes.

\section{Europeanization and External Relations}

While the literature on Europeanization is very well-developed, in the area of external relations it has been only lightly applied. After briefly reviewing existing work on Europeanization, this section turns to work that focuses on Europeanization in external relations. As this section notes, studies of Europeanization concerning external relations, as well as those of Poland and the CEECs, have tended to be dominated by work on downloading and compliance with EU policy. On closer inspection, this is surprising, in that while uploading, downloading, and socialization mark Europeanization studies in external relations, just as in other areas, it is uploading that warrants special attention, but has largely been overlooked. It is with this in mind that this section turns in greater detail to the literature on uploading.

As Wong has pointed out, Europeanization in foreign policy is novel because the policy area is most often considered as one reserved for states (Wong 2007: 321). Nonetheless, the EU also fits awkwardly into traditional international relations theory, where consequential policy and unique dynamics at the European level coexists with national foreign policies, rather than supplanting them (Wong 2007: 321). Europeanization scholars have attempted to capture this interplay between distinct national preferences and consequential decisions taken at the European level, and much like in other policy areas, Europeanization applied to foreign policy entails three interrelated processes, namely downloading, uploading, and socialization (Wong 2005, 2006, 2007; Major and Pomorska 2005; Gross 2009).

Downloading in foreign policy is a top-down process by which national policy is adapted to suit policy made at the European level (Wong 2007: 325; Pomorska 2007: 27). Some have associated this with policy convergence (Harcourt 2003; Wong 2007; Wong and Hill 2011; Gross 2009), although other scholars have found that the extent and the effects of this adaptation vary among member states (Börzel and Risse 2000; Wallace 2000; Menz 2011). Likewise, socialization refers to a process of 'cultural hybridization', whereby close and continued contact between national officials operating in Brussels imparts changes in their preferences and identities, creating officials who act in both their national and the broader European interest (Hill and Wallace 1996; Smith 2000; Wong and Hill 2011). With respect to both downloading and socialization, a key point of interest has been whether this affects the procedures by which member states pursue foreign policy, or the actual substance of the policy itself (Wong 2007: 322; Pomorska 2011: 169).

By contrast, uploading in foreign policy, as in other policy areas, entails a bottom-up process of promoting national foreign policy priorities by inserting them into decisions made at the European level. Indeed, member states have a number of incentives to project national policy onto European-level decisions, in that converting national policy into European policy increases their influence and may lower costs associated with pursuing controversial policies (Wong 2007: 
328). Likewise, uploading policy maximizes an individual member's benefit by matching European policy more closely to national preferences, while also lowering compliance costs (Börzel 2002: 195).

Some scholars in the Europeanization field, such as Menz (2011), conceptualize the Europeanization process as a bidirectional one, with both uploading and downloading processes interacting. Certainly, this is borne out in the casework on Poland. For instance, Pomorska and Wright have observed that, in foreign policy, Polish officials in Brussels have had better success in pursuing national objectives by adopting more moderate positions than those in Warsaw might like (Pomorska and Wright 2013: 157). This is to say that Polish attempts at uploading policy to Brussels have had feedback effects upon Polish policy, and nor is this limited to Poland. Indeed, Müller notes a similar moderating effect of European foreign policy upon national foreign policy initiatives of Germany (Müller 2011) and France (Müller 2013), for example.

Pomorska goes still further, finding that in external relations, some downloading by newer members may be a necessary condition for effective uploading. This is to say that some institutional adaptations are necessary to allow national policy-making processes to effectively interface with those at the European level (Pomorska 2011: 169). She notes that for Poland, this has begun to happen already, and that these adaptations to policy-making processes have made for slow, but important steps forward in its attempts to upload substantive policy to the European level (Pomorska 2011: 173).

Certainly, past work has considered uploading and downloading processes as interrelated, as in Börzel (2003). Similarly, work by Menz (2011) has linked uploading and downloading by conceptualizing the Europeanization process as a multi-level game. The examination of the CEECs by Pomorska (2011) and the subtle distinction between procedures and substance by Wong and Hill (2011) instead casts the relationship between the two not just as a 'reciprocal' one, but as a symbiotic one when it pertains to procedures being downloaded. Likewise, Pomorska's observation that early Polish attempts at influencing the European Neighbourhood Policy had foundered because its policymakers had yet to master 'playing the Brussels game' (Pomorska 2011: 175) suggests a similar role for elite socialization as an important catalyst in the uploading process.

With all of this said, however, several scholars, such as Wong and Hill (2011) and Pomorska (2011) have argued that in foreign policy, EU member states do retain distinct national interests, even if they have become more apt to frame them in European terms. Likewise, while Pomorska (2011: 170) has noted that the process of downloading in foreign policy has helped to produce a convergence in policy-making procedures, for example in restructuring and decentralizing the ministries of foreign affairs in some new members, in substantive policy, convergence among European member states has been 'patchy and uneven' (Pomorska and Wright 2013: 158), while member states' strategic objectives are not significantly impacted by engagement with other EU member states (Pomorska 2011: 173). As such, where the most aggressive policy uploading occurs where there is a misfit between national and EU foreign policies (Pomorska and Wright 2013: 160), the EU's combination of diverse national foreign policies with a uniform EU policy leaves ample scope for a misfit between them. As Wong notes as well, this uploading process is particularly important in external relations, where decision-making tends to be far more bottomup than in other policy areas (Wong 2007: 330).

This suggests that it is through member states jockeying to project their preferences onto EUlevel decisions that the Europeanization process is best captured in external relations. However, it is exactly this uploading process that has been less developed in the recent literature on 
Europeanization where new member states and external relations are concerned. Where the CEECs are considered, the attention of much scholarship in this field has been on the domestic impact of EU policies (e.g. Börzel and Risse 2012; Schimmelfennig and Sedelmeier 2004; Grabbe 2006), and variations therein (for example, in Knill and Tosun 2009; Bauer, Knill and Pitschell 2007; Zubek 2005).

Likewise, work on external relations has come to emphasize compliance with EU conditionality in candidate and ENP countries (for instance, Schimmelfennig and Sedelmeier 2004; Sedelmeier 2008, 2011; Kelley 2004; Levitz and Pop-Eleches 2010; Noutcheva and Aydin-Duzgit 2012). In other words, much of the Europeanization literature concerning Poland and the CEECs, as well as EU external relations, has been dominated by studies of downloading. To be sure, recalling Pomorska (2011) and others, uploading and downloading processes are interrelated, although these studies largely overlook the uploading process, as well as the subtle distinction between substantive policy and policy-making procedures that has allowed some scholars to capture the interdependent relationship between the two.

In their approaches to uploading, Börzel has divided member states into 'pace-setters' who actively attempt to shape EU policy in a given area, 'foot-draggers' who seek to block EU policy or extract side-payments as part of its passage, and ambivalent 'fence-sitters', who may form coalitions with either 'pace-setters' or 'foot-draggers' depending upon the issue (Börzel 2002: 208). What distinguish the three are their incentives for initiating common policies, and their ability to articulate and promote them at the European level. For Börzel, this is primarily determined by member states' level of economic development (Börzel 2002: 194), where economically-developed states are more likely to have complex policies and exacting regulatory standards at home and prefer to see the same at the European level, while those with lessdeveloped economies and regulations will find this overly onerous.

Likewise, these same economically-advanced member states are more apt to possess the necessary staff power, as well as access to information and experts to promote their interests at the European level than less advanced members (Börzel 2002:199). This separates the pacesetters who actively promote common European policies from foot-draggers and fence-sitters. Certainly, while an emphasis on economic development as a key feature distinguishing EU member states seems apropos in Börzel's (2002, 2003) rendering of uploading in the field of environmental regulation, this maps awkwardly onto uploading in external relations. Indeed, Pomorska and Wright find that in foreign policy, states are most apt to be aggressive about uploading where there is the largest misfit between EU policy and member preference, and where an issue is considered highly important by a specific member, irrespective of their level of economic development (Pomorska and Wright: 2013: 160). Having said that, comments by Pomorska (2011: 170-3), among others, do suggest that in external relations, administrative capacity plays a similar role as in Börzel's (2002) work, although this also suggests, contra Börzel (2002), that in external relations there may exist member states who lack the ability to upload, but who nonetheless have clearly-defined national policies in the area and an ambition to upload them.

Crucially, Börzel also points to member states' coalition-building and interestaccommodation skills as an important determinant of their success in uploading policy (Börzel 2002: 199-200; Börzel 2003: 7). She notes that Dutch policymakers' knack for formulating 'complicated, tailor-made compromises' has made them highly influential in some areas (Börzel 2002: 200), although this point has been less fully explored in these writings or subsequent ones. Indeed, far less attention has been given to the final steps of the uploading process, i.e. the 
dynamics surrounding the actual decisions that are made at the European level, although Howell (2004) and Schimmelfennig (2001, 2009) are exceptions.

Briefly, Europeanization in foreign relations turns on the interaction of socialization, downloading, and uploading. Previous work has found evidence of both socialization and downloading in external relations, but has also found that this has most impacted the procedures by which member states pursue their interests, and that in terms of the actual substance of foreign policy, member states do retain distinct interests. What this implies is that Europeanization in external relations is much more marked by bottom-up processes, but this is precisely where the literature has explored the least, particularly with respect to coalitionbuilding. The next sections take up this question of uploading, administrative capacity, and coalition-building in external relations with respect to Poland and the CEECs.

\section{Polish Administrative Capacity and EU External Relations}

Firstly, while by most measures, one might expect Poland and the CEECs to behave as footdraggers in the EU's external relations, on closer inspection, their position is rather more nuanced. As this section argues, on well-developed measures of uploading capacity, especially administrative capacity and staff power in Brussels, as well as elite socialization, the necessary adaptations and downloading of procedures needed to effectively influence EU policy have happened only slowly. As one might expect from Börzel (2002), in some cases, Poland has indeed engaged in obstructing and seeking side-payments, especially on the EU's southern and Turkish policy (Szymanski 2007: 552).

However, Poland and the CEECs are hardly opposed to new policy at the European level, as one might expect of a foot-dragger. Nor are they pragmatically ambivalent on external relations, as one might expect of a fence-sitter. In fact, Poland and the CEECs are active and consistent promoters of greater engagement with the eastern ENP countries. Put another way, rather than foot-dragging or fence-sitting, Poland and the CEECs have clearly been attempting to set the pace in EU external relations, but are only slowly developing the means to do so. This suggests that on these more traditional measures of influence, the impact of the eastward enlargement is limited, although administrative reforms and the slow process of elite socialization also suggest that the eastern members may become much more influential in the future.

As Börzel has argued, those member states who have the largest role in shaping policy at the European level tend to be those with access to a large bureaucratic staff, information, and policy expertise, and that their aim of projecting their preferences onto European policy is often furthered by offering expertise and seconding experts to Brussels (Börzel 2002: 200). By contrast, foot-draggers tend to lack staff power, specialized information, and area-specific expertise (Börzel 2002: 205), which limits their ability to articulate their preferences and to participate effectively in the negotiation process at the European level.

On this measure, Poland most closely resembles the latter. Dangerfield's point about extensive exchanges with Ukraine on a bilateral basis and under the auspices of the Visegrad group, for instance, suggests much expertise in dealing with the country (Dangerfield 2009: 1744). However, Poland struggles to deploy this to good effect, with shortages of staff and skills, as well as weak cooperation between offices in Warsaw and Brussels. It also struggles to deploy their staff power effectively in Brussels itself, although some scholars have noted that all of this is beginning to change. As Pomorska has noted, conducting an independent foreign policy is a relatively recent development for Poland, a point readily apparent in the acute staff 
and skill shortages characteristic of the Ministry of Foreign Affairs through the 1990s (Pomorska 2007: 31). Indeed, there has been a recent and significant expansion of the staff dealing with EU issues, although this process really only began in earnest after accession (Kaminska 2008b: 12); Copsey and Pomorska have also emphasized substantial recruitment challenges in the public service (Copsey and Pomorska 2010: 316-7).

While the presence of Polish foreign-policy experts in Brussels has expanded significantly since accession (Kaminska 2008a: 2), Peterson stresses the slow absorption of Polish administrators into the Brussels bureaucracy itself (Peterson 2008, 771). Furthermore, the irony noted by Pomorska that the expansion of Poland's Brussels offices has precipitated staff and skill shortages in the Ministry of Foreign Affairs, which is central to developing Poland's position on the EU's external policy in the first place, is a cruel one (Pomorska 2007: 40). All of this has been compounded by a notable generation gap between new staff, who appear much better-suited to dealing with EU policy and policymaking, and remaining pre-1989 hires who tend to be less adept at dealing with EU affairs (Copsey and Pomorska 2010: 316-7).

Just as importantly, several scholars have noted that the organization of Polish foreign policy staff has limited its ability to upload policy to the European level. This is to say that the process of adapting Polish policy-making procedures to suit EU external policymaking has been a slow one. Kaminska observes that administrative changes are evident in every government body engaged with EU issues since accession (Kaminska 2008a: 2), although Jakubek has argued that decision-making procedures surrounding Poland's foreign policy are still too complex to be effective when dealing with the EU (Jakubek 2008: 12).

Likewise, developing and executing a coherent strategy on the EU's external relations has been undermined, not just by weak coordination between the Ministry of Foreign Affairs and other key participants in the process, like the Committee on European Integration (Copsey and Pomorska 2010: 315), but by active competition between these bodies (Pomorska 2007: 35; Copsey and Pomorska 2013: 14). Some have pointed to a similar mistrust between Polish officials based in Brussels and their Warsaw-based counterparts (Pomorska 2007: 42; Copsey and Pomorska 2013: 18). All of that being said, Kaminska's point about recent changes in most institutions handling European policy (Kaminska 2008a: 2), and others' about expanding the staff and developing the expertise behind Polish proposals on the EU's external policy, are all well taken, and do suggest a much larger role for them in the future. At present, however, Copsey and Pomorska conclude that on the basis of administrative capacity, an older member such as France is likely to be far more influential, pointing to its success in promoting the Union for the Mediterranean (UfM) as an example (Copsey and Pomorska 2010: 320).

Similarly, several scholars have pointed to limited elite socialization as a hindrance to Polish uploading that has been slow to erode. As Kaminska has noted, prior to accession, most of the contact between Polish and EU officials occurred at a high level between political staffers, with very little engagement between the Polish civil service and permanent staff in Brussels (Kaminska 2008b: 15). Indeed, the process of socialization of Polish policy elites only began in earnest following accession (Pomorska 2007: 39). Consequently, the process of coming to terms with policy-making procedures in Brussels, and in engaging with permanent staff from other EU member states has been a difficult one, and one that has limited their ability to influence the EU's external policy. The experience of Polish staffers in Brussels has aptly been described as a case of 'culture shock' (Pomorska 2007: 35), although Kaminska's point that a lack of socialization was because of a lack of contact between Polish administrators and EU 
administration (Kaminska 2008b: 15) casts it as a problem unlikely to persist, with Poland now a full member of the EU.

While Poland does not fit the profile of a pace-setter, with its limited administrative capacity and still-developing Brussels-savvy, its strong preferences for more advanced policy at the European level do not mark it out as an obstructive foot-dragger, while its consistent and persistent attempts to promote a stronger eastern dimension in EU policy seem at odds with the pragmatic ambivalence of a fence-sitter. In some respects, this is not surprising, recalling Pomorska and Wright's point that a member state is most apt to be aggressive about uploading where there is a large mismatch between EU policy and its preferences (Pomorska and Wright 2013: 160), and Dangerfield's point that quite a bit of the EU's eastern policy was designed by the EU-15 prior to the 2004 enlargement, rather than by the new members (Dangerfield 2009: 1739).

As Copsey and Pomorska have noted, Poland has indeed voiced particularly strong preferences on eastern external relations (Copsey and Pomorska 2010: 311). Furthermore, all of the major Polish parties favour deepened ties with eastern non-members, making for only small changes in Poland's position between elections (Copsey and Pomorska 2010: 312-3). Likewise, a larger eastern dimension to EU policy is consistently popular among voters (Kaminska 2008a: 5; Szymanski 2007: 556), which would seem to suggest that there is no electoral advantage for Polish political parties in opposing closer engagement with Ukraine. Interestingly, some of Poland's more ardent positions on Ukraine mirror those of the electorate, sometimes to the point of alienating potential allies among the other member states (Jakubek 2008: 8).

All of this is borne out in Poland's consistent advocacy of greater engagement by the EU with its eastern neighbours. Poland began advocating in favour of closer ties between the EU and Ukraine even prior to accession (Copsey and Pomorska 2013: 3; Ganzle 2009: 1720). While the Eastern Partnership is perhaps the most conspicuous attempt by Poland and others at deepening the EU's eastern engagements, Poland has in the past been quite assertive on this point, for example on having Ukraine declared a market economy, or on visas (Pomorska and Wright 2013: 160). More interestingly still, in their European policy, Polish foreign policymakers are more apt to be criticized for an excess of ambition than the reverse (Jakubek 2008: 8; Copsey and Pomorska 2013: 4).

In short, along traditional measures of uploading capacity, specifically administrative capacity and use of expertise, Poland's ability to effectively upload its preferences is very limited, although over time this may change. However, it also does not behave like a foot-dragger or fence-sitter, as it is consistently pursuing initiatives at the European level, sometimes to the consternation of potential allies. What this suggests is that the impact of the eastward enlargement upon what gets uploaded in external relations is relatively small. As the next sections argue, however, the enlargement has had important effects upon coalition-building and decision-making processes that are likely to result in an eastward shift in the focus of the EU's external relations.

\section{Heterogeneous Membership and Laboured Decision-Making in External Relations}

While on most measures of uploading capacity one might expect that, for the time being at least, the impact of the EU's new members should be relatively small, it is in the dynamics surrounding coalition building that the eastward enlargement is likely to be the most consequential. Certainly, while a number of authors (following Schimmelfennig 2001) explain 
the eastern expansion of the EU as the result of its prior commitments to admit those countries that subsequently joined, following the accession of the eastern members, the EU has no such commitments outstanding with most ENP countries. This section will argue that at the same time as clear norms and rhetorical action (Schimmelfennig 2001) will not facilitate integration with ENP countries, new membership diversifies the EU's interests, and in turn complicates the resulting strategic behaviour by members on external relations. This has the effect, in general, of making EU decision-making more laboured, and the process by which member states upload their preferences in foreign policy more difficult.

Elaborating his concept of rhetorical action into 'rhetorical entrapment' (2001), Schimmelfennig argues that states still pursue national interests, but channel them through EU norms (Schimmelfennig 2009: 502), which can favour closer ties with non-members whose behaviour and past EU commitments resonate with EU norms. This may serve to commit normbound member countries to courses of action that defy a more narrow reading of their interests. However, entrapment requires favourable external conditions, and EU norms that are determinate, i.e. that are clearly stated, providing unambiguous policy prescriptions, and that are 'relevant', or salient in the EU's dealings with a given country (Thomas 2009: 346). In his earlier work, Schimmelfennig (2001) argued that these norms and the resulting rhetorical entrapment were crucial to explaining the opening of accession talks with what are now the EU's eastern members, despite the incongruence of expansion with the preferences of several member governments. This is to say that with these countries, EU norms had been 'determinate' and 'relevant', in that the EU had previously made clear commitments to them around the opening of accession talks, which was actively pursued by some member states and the countries in question.

Youngs, however, contrasts the EU's contact with recent members with its relations with other neighbours, as no such norms on accession exist in the EU's dealings with most ENP countries. In these cases, no clear commitments on EU membership were ever made to ENP countries, which, as Youngs (2009: 371) points out, results in strategic behaviour by member governments towards these countries, rather than the norm-bound cooperative behaviour that resulted in closer ties to several CEECs and their eventual accession. Certainly, normative entrapment played a role in EU support for the Orange Revolution in Ukraine, but Youngs (2009: 373) insists that this speaks to EU norms on promoting democratization, which does not extend to closer ties, to say nothing of accession. He notes elsewhere that most decision-making by member states on EU policy towards Ukraine have been driven by strategic calculation, and not constrained by EU norms (Youngs 2011: 45).

Moreover, the short time since the accession of Poland and the other CEECs has not been sufficient to affect EU norms or commitments on external relations (Copsey and Pomorska 2010: 305). All of this is to say that towards the EU's eastern neighbours, and most of the ENP countries besides, the sorts of norms surrounding membership that helped facilitate closer ties and eventual accession for the CEECs are either absent or ill-defined. This carries the implication that for the foreseeable future, members' decision-making will continue to be bound by strategic calculation, rather than facilitated by norms.

At the same time as the pre-requisites for rhetorical entrapment are not present in the EU's dealings with most of its neighbourhood, the recent rounds of enlargement have complicated the decision-making processes governing the EU's external relations. This is what Verdun (2005), for instance, has in mind when she notes that enlargement has presented challenges for the governability of the EU. Indeed, where new initiatives, such as partnership agreements and the 
like, require Council approval, absent the catalyst of rhetorical entrapment, a larger and more diverse membership makes gaining this approval far more difficult.

With this in mind, Zimmer, Schneider, and Dobbins point to more complex voting patterns because of the more heterogeneous interests represented in Council votes. They also point to the more ad hoc nature of Council coalitions on matters of external relations as a result of a larger membership (Zimmer, Schneider, and Dobbins 2005: 415). Also complicating matters are the sheer number of possible coalitions for various initiatives. Where member consent is a necessary condition for EU action, one can expect decision making in general to be more fractious, inconsistent, and laboured as a result of the eastward expansion. This is to say that the process of uploading national policy to the EU level will, in general, be slower and far more difficult as a result of the CEECs' accession because of the challenges that it poses for coalition building. Indeed, as members can be expected to behave strategically (Youngs 2009: 371), these considerations become especially pertinent in the EU's dealings with its neighbours.

At the same time as decision-making has become more complex for the European Union, the new members have also tended to favour greater protectionism in trade, which often manifests itself in a preference for more regulation (Zimmer, Schneider, and Dobbins 2005: 415), a point echoed by Elsig (2010). This means that the larger acquis that results makes legal harmonization far more challenging for countries seeking to deepen their ties with the EU. It also means that one of the more enticing incentives available to the EU in its dealings with non-members, i.e. access to the Single Market, is less appealing to target countries than it might be otherwise, while the protectionist impulses at the root of this development mean that it will be offered less willingly by the EU in any case.

In sum, the eastern enlargement greatly reduced the number of external countries with whom the EU has 'determinate' and 'relevant' norms on accession. This means that the rhetorical entrapment that facilitated dealings with the new members is largely absent, while the additional members themselves have also made the strategic behaviour that has resulted far more complex. Indeed, the heterogeneity of new interests introduced into Council voting, as well as a preference for more and increasingly elaborate regulation, complicates both the EU's ability to make decisions about its external relations, and makes the harmonization that is so central to EU conditionality increasingly difficult. In other words, their accession poses new challenges for the coalition-building process that is so crucial to uploading.

\section{CEEC Preferences and Bypasses to Enhanced Eastern Ties}

While the complications and lack of favourable norms governing the EU's external relations following enlargement may be a hindrance to uploading in EU external relations in general, the new membership brings preferences and a willingness to collaborate that alleviate some of these difficulties in the EU's dealings with its eastern neighbours, although not necessarily with other ENP countries. The fact that Poland and the new members are increasingly adept at coalitionbuilding should accentuate this dynamic. This section will argue that while the addition of new members has made EU decision making more cumbersome in general, these difficulties are far less pronounced in its dealings with the eastern ENP countries in particular. This is to say that while the CEECs' accession makes uploading a more fraught process, it also makes the uploading of their preferences in particular much less difficult. 
Certainly, a number of authors are correct to point out that the eastern expansion has been a key contributor to recent enlargement fatigue (e.g. Ganzle 2009: 1717), and still others for pointing out that the lack of credible accession prospects may limit compliance with EU conditionality (Kelley 2006). However, not only does the eastern enlargement bring fresh geopolitical considerations for the EU as a whole, but the EU's new members also bring with them a specific, and crucially, a shared interest in greater engagement with the western Newly Independent States (NIS), specifically Ukraine, Belarus, and Moldova (Dangerfield 2009, 1739). This means that to the extent that they pursue these goals consistently, and are willing to collaborate in pursuit of them, the more laboured decision-making that, in general, can be expected to accompany a larger membership, should be less pronounced on issues relating to the EU's eastern neighbours. Under these conditions, the heterogeneity of interests and weak, fractious coalitions that hinder EU decision-making more broadly should be less salient in its eastern policy, and hence, less of an impediment to it.

For instance, trade ties to the EU's eastern neighbours are particularly strong among the Baltic countries, as well as Poland, Slovenia, Romania, and Hungary (Dabrowski 2011: 188). As Dabrowski notes, while much of these countries' trade is with other EU members, the share of these countries' trade with the NIS countries is, unsurprisingly, well above the average for the EU-27 (Dabrowski 2011: 188). In addition to having deep trade ties with its non-EU neighbours, particularly Ukraine, Poland's poorest regions are in the east, and would be the largest beneficiaries of closer ties with its neighbours (Copsey and Pomorska 2010: 312). Although this dynamic is particularly pronounced with Poland, this is also the case with some of the poorer regions of Romania and Hungary (Eurostat 2012: 2). With all of that said, Fritz cites in particular limits on cross-border activity under Schengen as being especially restrictive to economic growth in these border regions (Fritz 2005: 205). With this in mind, where deeper trade ties are one of the objectives of their dealings with their eastern neighbours, one expects the protectionist impulses that the CEECs display in the EU's dealings with other ENP countries to be far less acute, as well.

Similarly, Dabrowski, among others, cites common experiences in the $20^{\text {th }}$ century as contributing to Poland's preference for closer ties with the NIS. Dabrowski highlights the shared, albeit varying experience of communism in the $20^{\text {th }}$ century, but also the common experience of inclusion in the Russian empire prior to the First World War. He also points to cultural and linguistic linkages between several eastern EU members, Poland chief among them, and some of their neighbours (Dabrowski 2011: 186). Thinking along these lines, Szymanski finds common experience behind Polish promotion of Bulgarian and Romanian accession despite prophetic questions over the extent of their compliance with the convergence criteria (Szymanski 2007: 553).

Furthermore, while she sees them as overblown, Fritz cites concerns among the CEECs that their divergence from the NIS may constitute a new partition of the region (Fritz 2005: 193), while in security and border control in particular, new members bear the worst of ill-considered eastern policy (Dangerfield 2009: 1739). This dynamic is particularly acute in migration policy, for instance. Indeed, as migration across the EU's eastern border has grown substantially, contra concerns in mature members states about immigration, many irregular and illegal migrants from the EU's eastern neighbours, for geographical, cultural, and linguistic reasons settle in its eastern members (Dabrowski 2011: 189). This has the implication, firstly, that these countries bear the worst of the EU's limited success in collaborating with the NIS on migration, and, secondly, that 
these countries have a strong, and crucially, a shared interest in pursuing visa agreements and other avenues for legal migration with these countries (Dabrowski 2011: 189).

With all of this in mind, Polish elites tend to favour Ukrainian accession more than older member states (Szymanski 2007: 549-50), while many of the new member states share these preferences (Dangerfield 2009: 1739). In other words, with their goals of deeper ties and the opening of accession talks with the EU's eastern neighbours, the CEECs certainly add a new flavour to the interests acting upon EU's external relations.

All of this creates compelling incentives for active involvement in EU foreign policy making, as well as concertation to that end by the new members. Crucially, in Council voting and coalition building on external relations, Polish elites have acted consistently on these incentives. Indeed, Poland has been extremely active in Council in promoting ties with Ukraine, even if this has become more challenging after the 2006 Ukrainian elections (Szymanski 2007: 551), and doubtless more difficult still following the presidential election in 2010. Nonetheless, Poland has responded to these setbacks by pushing for greater incentives for compliance and the opening of membership talks with Ukraine as a means of consolidating the gains of the Orange Revolution (Youngs 2011: 45). Youngs notes that while these proposals met with strong opposition from Germany, the compromise solution saw Ukraine being offered more of the acquis (Youngs 2011: 42). Similarly, while Poland has been far less active in promoting closer ties to Turkey and the Balkan states (Szymanski 2007: 556), it has also attempted to use the Turkish accession talks as a precedent for opening similar discussions with Ukraine (Szymanski 2007: 552).

Just as importantly, the new member states' shared interest and willingness to collaborate on deepening engagement with eastern neighbourhood countries defies the fragmentation that would otherwise be expected with a larger membership. Indeed, contrary to the fractiousness that might be expected among member governments on relations with other ENP countries, the new members have had a degree of success in collaborating among themselves to influence the EU's external relations.

Thinking along these lines, Dangerfield, for instance, cites the example of the Visegrad group, which was originally created by the Czech Republic, Hungary, Poland, and Slovakia to coordinate their progress towards EU accession, but which has been converted to promote closer ties to other NIS countries (Dangerfield 2009: 1737-8). This group has been found pushing for closer eastern ties than envisioned under the ENP, as well as encouraging the accession aspirations of Ukraine in particular (Dangerfield 2009: 1741), and pushing for enhanced incentives for these countries, such as greater access to the Single Market, and fewer travel restrictions.

Certainly, while its activities towards Russia have been limited, in coordinating their positions on its other eastern neighbours, it has only become more active (Dangerfield 2012: 964; Fawn 2013: 346-7). It has also become a vehicle for engaging with other member states, with meetings between the V4 on the Eastern Partnership coming to include Sweden, Romania, Bulgaria, and the Baltic states, for example (Dangerfield 2009: 1743). In any event, this push to allow a large neighbour such as Ukraine greater access to the Single Market is even more striking when one recalls the more protectionist bent of most CEECs. Dangerfield points to the Visegrad group's facilitation of the Eastern Partnership as one of its most important achievements (Dangerfield 2009: 1742), notable in particular for its inauguration despite French and German uneasiness. Furthermore, at the same time as the group has lobbied for a more comprehensive eastern strategy, it has actively collaborated with NIS countries, with information sharing and bilateral 
exchanges intended to facilitate compliance with EU conditionality, both bilaterally through twinning projects, and through meetings organized under the auspices of the Visegrad Group (Dangerfield 2009: 1744, 1749).

While new member states have been keener to engage with Ukraine, Belarus, and Moldova, and keen to collaborate among themselves, Poland in particular has had a degree of success in building coalitions in favour of enhanced eastern engagement with older members, where it had previously struggled (Youngs 2009: 362-3). This is to say that, alongside longstanding collaboration with the other CEECs, Poland increasingly has the tools to navigate the added complexity that its accession introduces into EU decision-making processes. Early Polish attempts at influencing the EU's external policy tended to be overly ambitious and failed to resonate with other members (Copsey and Pomorska 2013: 4). This stands in contrast with the Eastern Partnership, which though seemingly less ambitious than the Union for the Mediterranean, won support for its smaller scope and incremental approach, as well as subtle couching of the issue in terms of 'regional cooperation' (Copsey and Pomorska 2013: 5-6).

The Eastern Partnership was notable as well because it was the product of a newfound willingness to collaborate with Sweden. In other words, not only has Poland been more willing to present its preferences in the form of more moderate and more broadly appealing policies (Pomorska and Wright 2013: 157), but it has also become more adept at promoting them by engaging other members. With this in mind, Jakubek labels Poland as an 'awkward partner' through its early years as an EU member because of a confrontational approach to EU policy (Jakubek 2008: 8), while Copsey and Pomorska are hardly alone in pointing out that the adversarial style of the Kaczynskis has served to isolate the country at times (Copsey and Pomorska 2010: 318), taking a high-profile split with Germany over a 2006 veto of a Partnership and Cooperation Agreement with Russia as a case in point (Copsey and Pomorska 2010: 313).

Nonetheless, Copsey and Pomorska also note that it is in coalition building and 'persuasive advocacy’ where Poland has improved most dramatically (Copsey and Pomorska 2013: 12). As such, they are also not alone in noting that a more conciliatory approach since the formation of the post-Kaczynski government in 2007 has marked a turning point in Poland's relations with other EU members, notably Germany (Copsey and Pomorska 2013: 13). Likewise, Polish representatives in Brussels are increasingly adept at framing issues in terms of community interests, where previously they had struggled to present their preferences persuasively (Copsey and Pomorska 2010: 317).

Copesy and Pomorska have expressed reservations about Poland's newfound collaborative streak, questioning whether or not the practice will become institutionalized (Copsey and Pomorska 2013: 20). Nonetheless, on policy towards Ukraine, Poland has had recent success in coordinating with Austria and the UK, as well as the Scandinavian countries (Youngs 2009: 3623). Its new relationship with Sweden has proved fruitful, not only through mutual support for shared interests, but also because it has offered Polish policymakers the opportunity to learn from Swedish counterparts more seasoned in navigating the policy-making process in Brussels (Copsey and Pomorska 2013: 20). All of this means that not only has enlargement brought new interests and pre-made coalitions in favour of greater eastward engagement, but that they also resonate with the interests of some existing EU members. Indeed, one wonders whether these interests of these older members would have found expression in EU policy absent the support of the EU's eastern membership.

In brief, defying the fragmentation and laboured decision making that would be expected to mark relations with other ENP countries, the common interest in greater eastern engagement 
among the CEECs redresses some of the challenges in Council voting and coalition building that have accompanied enlargement, at least when addressing relations with the EU's eastern neighbours. With respect to Ukraine, these countries have enjoyed a degree of success in collaborating both with each other, and with older EU members on deepening ties. All of this means that the challenges of an expanded membership should be less pronounced in relations with Ukraine, Moldova, and Belarus than with other neighbourhood countries. This has the implication that as a result of the eastward enlargement, these ENP countries in particular can be expected to be the focus of more EU external agreements than with other ENP countries.

\section{Empirical Implications}

Thus far, this paper has argued that the changes that the eastern enlargement has brought to decision making in the EU should contribute to an eastward shift in its external relations. This section argues that the eastward enlargement and the resulting attentiveness to the NIS are likely to deepen the EU's differentiated approach to its neighbours, but may also help redress the EU's problems with ambiguous goals, and the weak incentives it extends to achieve them. This is certainly not a guarantee of success in its dealings with its neighbours, but these changes do help redress some of the self-imposed limitations upon the EU's policy towards its eastern neighbours. While the CEECs have been most keen to indulge and promote the accession aspirations of eastern neighbours, chiefly Ukraine, some of the more substantial advances in European external relations with other neighbourhood countries, particularly the Union for the Mediterranean, explicitly rule out eventual membership, a point that some authors find has soured relations with these southern neighbours (Ozcurumez and Bolukbasi 2011), and which does suggest limits on the degree of possible integration between them and the EU.

Dangerfield's point that the CEECs' continued interaction with western NIS countries serves to strengthen bilateral ties (Dangerfield 2009: 1744), and that the reluctance of the CEECs to explicitly rule out eventual accession by these countries, suggests that closer eastern relations driven by the new members may have feedback effects that would encourage still further engagement with eastern ENP countries, but that are not present in relations with southern ENP members. The irony is cruel, indeed, when considering how several Mediterranean countries' prospects for making progress on the democratic and human rights indicators stressed by EU conditionality have improved dramatically as a result of the Arab Spring, in contrast developments in Ukraine and Belarus occurring at the same time.

Furthermore, while the EU has deliberately avoided making commitments on accession in its dealings with ENP countries, one wonders whether these deepening ties to the east, as well as active support by the CEECs for opening membership talks with the eastern ENP countries, might, with the exception of the Balkans, make the opening of talks more likely in the east than elsewhere. With this in mind, while the European Neighbourhood Policy initially took a similar view of future expansion as the UfM, Dangerfield also points out that this was because the ENP was designed by the EU-15 prior to the eastern enlargement, and doesn't reflect the influence of the new members (Dangerfield 2009: 1739). At the same time, the fact that the Visegrad group, for instance, in drawing a distinction between 'neighbours of Europe', whose integration with the EU it does not promote, and 'European neighbours', who it does, suggests that very different assumptions about the 'neighbourhood' underlie EU-12-sponsored initiatives (Dangerfield 2009: 1741). This is especially striking in light of this paper's argument that these initiatives stand to be relatively more prominent in the EU's external relations. 
Furthermore, the policy implications of these differing assumptions may have crucial and unintended consequences for the EU's response to current events. The EU-15's explicit rulingout of accession for Mediterranean neighbours would seem to suggest limits to the depth of its willingness to engage with them, and the credibility of its long-term commitments to them. By contrast, the unwillingness of the EU-12 to rule out accession for the eastern neighbours would seem to suggest that despite the gravity of events in North Africa since 2010, these changes seem unlikely to alter this pattern of greater eastern engagement in EU external relations.

Moreover, while the EU struggles with credibility problems and with limited receptivity by neighbourhood countries because of a lack of clear accession prospects for these countries, Dangerfield in particular has pointed out that the bilateral ties between the CEECs and these eastern neighbours have helped redress problems with receptiveness, particularly with respect to Ukraine (Dangerfield 2009: 1744). Interestingly, these exchanges have helped to deepen the sort of bilateral ties between the CEECs and their eastern neighbours (Dangerfield 2009: 1744) that help account for their interest in deeper engagement in the first instance. In other words, this interest in deepening ties with the eastern ENP countries, and the ways in which the new members pursue them, are mutually reinforcing. This would seem to suggest room for further strengthening of CEEC preferences for closer ties with their neighbours at the expense of engagement with other ENP countries.

None of this is to suggest that holding the continued attention of the EU necessarily alleviates the internal problems, many of them quite substantial, which have hampered the progress of these eastern neighbours on EU conditionality in the past. Needless to say, successful deepening of formal ties through the meeting of EU conditionality depends very much upon factors outside of the EU's direct control, and even authors with the most optimistic outlook on Ukraine's compliance, for instance, note the significant internal complications working against compliance with EU conditionality (E.g., Fritz 2005: 207). Despite the optimism immediately following the Orange Revolution, halting progress on compliance with EU conditionality and an erratic balancing of relations with the EU and Russia are more the rule than the exception for a succession of Ukrainian governments (Pentland 2007), a point reiterated by the behavior of the former Yanukovych government.

The same may be said of Belarus, whose internal and external politics perpetually leave it closer to sanctions than to greater cooperation with the EU (Pentland 2007: 130). This comes despite growing interest in engagement on the part of the European Union since 2008-9 (Bosse 2009: 216). The lack of receptiveness on the part of Belarus is such that Bosse goes so far as to suggest that it challenges the hitherto-accepted notion in the academic literature that the EU's ability to extend its rules and norms is a given (Bosse 2009: 217).

While increased attention should not be conflated with increased cooperation and successful engagement, the influence of the CEECs does help redress some of the pathologies in the EU's approach towards its eastern neighbours. For example, Pentland notes that weak membership prospects have consistently placed limits on Ukraine's receptiveness towards the EU's overtures, even before the 2004 enlargement (Pentland 2007: 140). Similarly, Dabrowski summarizes the position held by many in the field that the effectiveness of the ENP has long been limited by the combination of weak incentives and exacting expectations placed upon NIS countries for reforms and cooperation (Dabrowski 2011: 195). Bosse also notes that, Belarusian intransigence aside, relations with Belarus have been hampered by an incoherence in the EU's goals, with persistent clashes between its strategic-economic goals and its normative-ideational ones (Bosse 2009: 219), and nor are relations with Belarus unique in this respect. The opening of accession talks 
with Ukraine, or Belarus and Moldova, for that matter, seems unrealistic in the foreseeable future. However, it is noteworthy that the CEECs have consistently worked in favour of opening talks, and show no signs of relenting on EU membership for these countries.

Short of opening accession talks, the CEECs have pushed consistently for greater incentives to be offered to their eastern neighbours. Offering incentives such as improved market access and concessions on visas likely benefit these members as much as their neighbours. Where they succeed in translating this impulse into EU policy towards their eastern neighbours, the CEECs' influence may help address the problem of weak incentives offered to the eastern ENP countries. At the same time, whereas for the rest of the EU, ultimate goals of integration with Ukraine have traditionally been ill-defined, the CEECs' preference for closer ties as an end in itself does lend an element of clarity in the EU's eastern policy that would otherwise be absent.

Briefly, the changes in EU decision-making dynamics as a result of the eastward enlargement carries the likely implication of deepening the EU's differentiated approach to its neighbours, with its eastern neighbours being the beneficiaries of greater EU attention at the expense of its southern ones in particular. Moreover, while greater attention by the EU should not be confused with greater success in its eastern policy, greater coherence and a preference for more generous incentives do help address some of the traditional shortcomings of the EU's eastern policy.

\section{Theoretical Implications}

While the focus of this article has been empirical, some theoretical implications of its findings are evident. This section argues that coalition building has been under-examined in the Europeanization literature, while it is not just the capacity and coalition-building skills that matter, but the presence of other members with complimentary preferences that help define states' success at uploading. It also argues that a more nuanced understanding of administrative capacity and the relationship between uploading and downloading are evident in a study of the CEECs that might not have been obvious to past researchers.

Firstly, coalition building in the Europeanization literature has been underappreciated as a determinant of successful policy uploading. Indeed, while it finds a place in even early formulations by Börzel (2002; 2003), it is far less developed in this early literature and subsequent work. To be sure, while foundational work in the area predates the 2004 and 2007 enlargements, subsequent work pointing to the complications that the larger membership has brought make redressing this in future research all the more pressing.

Likewise, what the CEECs' shared interest in greater eastern engagement suggests is that not only do the intrinsic features of a given member state matter for their success in uploading policy, but the policies themselves and the extent to which they resonate with other members matter as well. Put another way, the literature singles out as successful uploaders member states with access to staff, expertise, and a talent for 'selling' their preferences to other members (Börzel 2002; 2003), but this suggests that another catalyst might be the presence of other member states with strong and similar preferences on an issue. It also suggests that members' uploading success may vary systematically by policy area, even if their staff are equally numerous and coalition-building skills just as sharp between issue areas. Furthermore, what the influence of the Visegrad group also suggests is that not only complimentary preferences, but institutionalized fora for collaboration and well-established networks between EU member states may be consequential, as well. This is further to Crouch's observation that the 'middle-level' in the Europeanization process, i.e. links between governments through bilateral exchanges or 
transnational actors, has been given insufficient attention by Europeanization scholars (Crouch 2013).

Moreover, a closer examination of Poland's administrative capacity suggests some additional subtleties not fully articulated in the literature. The fact that some scholars have noted in Poland a consistently strong interest in its eastern neighbours, as well as extensive experience in dealing with them, both historically and in the form of recent bilateral exchanges (Dangerfield 2009: 1744), would seem to suggest that they possess the sort of area-specific expertise that characterizes a pace-setter. Likewise, in numbers at least, the Polish civil service and its presence in Brussels has expanded dramatically (Kaminska 2008a; 2008b). An examination of the Polish experience suggests (as in Copsey and Pomorska 2013; Jakubek 2008; Kaminska 2008b; Pomorska 2007), that the way in which expertise and staff are marshalled matters as well, in two respects: firstly, to the extent that large staffs spread out over multiple offices in the capital and in Brussels coordinate their efforts effectively, and secondly, to the extent that staff are organized and behave in a way that is compatible with the unique policy-making processes in Brussels. In other words, administratively, there is a distinction to be made between 'capacity' and 'capacity for uploading'.

Finally, what these struggles with administrative reform also highlight is the importance of the relationship between uploading and downloading. This has been characterized as a reciprocal one, and certainly, past scholarship has hardly been ignorant of the fact that the two interact. Nonetheless, these struggles in Poland to adapt not just to the finer points of the acquis, but also to refashion their policy-making machinery recalls two subtleties less considered in the current literature. The first is the distinction made by Wong and Hill (2011) between the downloading of substantive policy and downloading policy-making procedures, and the second, that among new members and concerning procedures, a certain degree of downloading is necessary to be able to upload effectively.

This is not a distinction that would be readily apparent in earlier literature that considered first and foremost older EU members with more mature administrative systems and policy-making processes as their window into the Europeanization process. Nonetheless, it does underscore that the relationship between uploading and downloading is not just reciprocal, but in some cases symbiotic, which is all the more significant given how acute the issue of adapting policy-making procedures, and not just transposing the acquis, has been in both recent and potential EU members.

In summary, this article's findings suggest that coalition building has been underappreciated in the existing literature following enlargement, while the preferences of other members, and not just the characteristics of an erstwhile uploader, are important, as well. Furthermore, additional subtlety is needed in treating administrative capacity, while greater sensitivity in subsequent work to the distinction between policy-making procedures and substantive policy would better capture the symbiosis between uploading and downloading.

\section{Conclusion}

In conclusion, while one can expect the impact of the eastward enlargement upon the EU's external policy to be small on measures of administrative capacity and elite socialization, its impact upon coalition building may be far more consequential. The eastward expansion can be expected to complicate the EU's relations with neighbour countries because of more complex interactions between members. Because it has explicitly avoided the sort of commitments that 
might lead to rhetorical entrapment, this can be expected to be less of a hindrance to the EU in its dealings with Ukraine in particular, but also with Moldova and Belarus, than with other ENP countries. Indeed, the CEECs bring a strong preference for enhanced ties to these countries, and have had a degree of success in collaborating amongst themselves to this end. This simplifies the strategic behaviour necessary to facilitate ties between the EU and these countries, making the process of uploading an eastern dimension to the ENP less laboured.

All of this means that the shared preferences and collaboration of the new members bypass a number of difficulties that they introduce into the EU's external relations, so long as they centre upon its eastern neighbours. Hence, the eastward enlargement of the EU encourages an eastward shift in EU foreign relations by introducing complications that hamper decision making in general, but not dealings with the eastern neighbours in particular. This means that one can expect to observe more activity on the EU's part in the form of dialogues and proposed initiatives focused on the eastern ENP countries than would otherwise be the case.

In closing, while this paper has argued that attempts at deepening engagement will be more frequent as a result of the eastern enlargement, this does not necessarily suggest that these engagements will be fruitful. The successful transfer of EU rules and norms depends in no small part upon the domestic politics of individual ENP countries (Börzel 2011), a point underscored by the row over Ukraine's association agreement. Nonetheless, it does suggest that more generous incentives will be applied to encourage compliance with EU conditionality, that the measures of its success will be more clearly defined, that greater scrutiny and responsiveness to its failures will characterize the EU's external relations with its eastern neighbours in the future, and that the differentiated approach that the EU takes with its near-abroad will deepen.

\section{REFERENCES}

Bauer, Michael, Christoph Knill, and Diana Pitschel, "Differential Europeanization in Eastern Europe: The Impact of Diverse EU Regulatory Governance Patterns”, Journal of European Integration 29 (2007): 405-23

Börzel, Tanja, "Pace-Setting, Foot-Dragging, and Fence-Sitting: Member State Responses to Europeanization”, Journal of Common Market Studies 40 (2002): 193-214

Börzel, Tanja, “Shaping and Taking EU Policies: Member State Responses to Europeanisation”, Queen's Papers on Europeanisation (2003): 1-15

Börzel, Tanja, "When Europe Hits...Beyond its Borders: Europeanization and the Near Abroad”, Comparative European Politics l (2011): 394-413

Börzel, Tanja and Thomas Risse, "When Europe Hits Home: Europeanization and Domestic Change”, European Integration Online Papers 4 (2000): 1-20

Börzel, Tanja and Thomas Risse, “From Europeanisation to Diffusion: Introduction”, West European Politics 31 (2011): 1-19 
Bosse, Giselle, "Challenges for EU Governance through Neighbourhood Policy and Eastern Partnership: the Values/Security Nexus in EU-Belarus Relations”, Contemporary Politics 15 (2009): 215-27

Copsey, Nathaniel and Karolina Pomorska, "The Influence of Newer Member States in the European Union: The Case of Poland and the Eastern Partnership”, Europe-Asia Studies 66 (2013): 1-23

Copsey, Nathaniel and Karolina Pomorska, "Poland's Power and Influence in the European Union: the Case of its Eastern Policy”, Comparative European Politics 8 (2010): 304-26

Crouch, Graeme, “A Struggle for Influence: A Multi-levelled Appreciation of the Europeanisation Process”, in EU Enlargement: Current Challenges and Strategic Choices, ed. Finn Laursen (New York: Peter Lang International Academic Publishers 2013): 131-52.

Dangerfield, Martin, “The Contribution of the Visegrad Group to the European Union's ‘Eastern’ Policy: Rhetoric or Reality?”, Europe-Asia Studies 61 (2009): 1735-55

Dangerfield, Martin, "Visegrad Group Co-Operation and Russia”, Journal of Common Market Studies 50 (2012): 958-74

Dabrowski, Marek, “Economic Relations Between the EU and CIS”, in EU Eastern Neighbourhood, eds. Marek Dabrowski and Marlya Maliszewska (Berlin: Springer 2011): 185200

Debardeleben, The Boundaries of EU Enlargement: Finding a Place for the Neighbours (New York: Palgrave Macmillan 2008)

Elsig, Manfred, "European Union Trade Policy After Enlargement: Larger Crowds, Shifting Priorities, and Informal Decision-Making", Journal of European Public Policy 17 (2010): 78198

The Economist "Germany and Eastern Europe: Love in a Cold Climate" (February 4 2012)

Eurostat, "Regional GDP Per Capita in 2009: Seven Capital Regions in the Ten First Places”, Eurostat News Release 38/2012 (March 13 2012). Accessed on 1 May 2014. http://epp.eurostat.ec.europa.eu/cache/ITY_PUBLIC/1-13032012-AP/EN/1-13032012-APEN.PDF

Fawn, Rick, “Visegrad: Fit for Purpose?”, Communist and Post-Communist Studies 46 (2013): 339-49

Fritz, Verana, "New Divisions in Europe? East-East Divergence and the Influence of European Union Enlargement”, Journal of International Relations and Development 8 (2005): 192-217 
Ganzle, Stefan, "EU Governance and the European Neighbourhood Policy: a Framework for Analysis”, Europe-Asia Studies 61 (2009): 1715-34

Grabbe, Heather, The EU's Transformative Power (New York: Palgrave 2006)

Gross, Eva, The Europeanization of National Foreign Policy: Continuity and Change in European Crisis Management (New York: Palgrave Macmillan 2009)

Harcourt, Alison, "Europeanization as Convergence: The Regulation of Media Markets in the European Union”, in The Politics of Europeanization, eds. Kevin Featherstone and Claudio Radelli (Oxford: Oxford University Press 2003): 179-202

Hill, Christopher and Helen Wallace, "Introduction: Actors and Actions", in The Actors in Europe’s Foreign Policy, ed. Christopher Hill (London: Routledge 1996): 1-16

Howell, Kerry, "Developing Conceptualisations of Europeanization: Synthesising Methodological Approaches”, Queen’s Papers on Europeanization 3 (2004): 1-13

Jakubek, Jowanka, "Polish Experiences with European Policy Coordination 1991-2006”, Reinventing Poland: Economic and Political Transformation and Evolving National Identity, in eds. Martin Myant and Terry Cox (New York: Routledge 2008)

Kaminska, Joanna, "Influencing the European Union's Policy Towards Belarus: Poland in the Enlarged European Union”, Politics and International Relations Working Paper 9 (2008a): 1-7

Kaminska, Joanna, "Taking or Shaping? Poland and the Eastern Dimension of the Common Foreign and Security Policy (CFSP) of the EU”, Cypress Centre of International Affairs Working Paper 2008 (2008b): 1-31

Kelley, Judith, "New Wine in Old Wineskins: Promoting Political Reforms through the New European Neighbourhood Policy”, Journal of Common Market Studies 44 (2006): 29-55

Knill, Christoph and Jale Tosun, "Post-Accession Transposition of EU Law in the New Member States: a Cross-Country Comparison”, European Integration Online Papers Special Issue 2 (2009): $1-18$

Levitz, Philip and Grigore Pop Eleches, "Why No Backsliding? The European Union’s Impact on Democracy and Governance Before and After Accession”, Comparative Political Studies 43 (2009): 457-85

Major, Claudia and Karolina Pomorska, “Europeanization: Fashion or Framework?”, Fornet CFSP Forum 3 (2005): 1-8 
Menz, Georg, "Stopping, Shaping and Moulding Europe: Two-Level Games, Non-State Actors and the Europeanization of Migration Policies”, Journal of Common Market Studies 49 (2011): 437-62

Müller, Patrick, “The Europeanization of France’s Foreign Policy towards the Middle East Conflict - From Leadership to EU-Accommodation”, European Security 22 (2013): 113-28

Müller, Patrick, “The Europeanization of Germany’s Foreign Policy toward the IsraeliPalestinian Conflict: Between Adaptation to the EU and national Projection”, Mediterranean Politics 16 (2011): 385-403

Noutcheva, Gergana and Senem Aydin-Düzgit, "Lost in Europeanisation: The Western Balkans and Turkey”, West European Politics 35 (2012): 59-78

Ozcurumez, Saime and Tolga Bolukbasi, “Of Context, Interaction and Temporality: Historical Institutionalism and Turkey's approach to the ENP and the UFM”, Comparative European Politics 9 (2011): 524-42

Pentland, Charles, "Ukraine and the European Neighbourhood Policy”, in The Boundaries of EU Enlargement: Finding a Place for Neighbours, ed. Joan DeBardeleben (New York: Palgrave 2008): 129-46

Peterson, John, "Enlargement, Reform, and the European Commission. Weathering a Perfect Storm?”, Journal of European Public Policy 15 (2008): 761-80

Pomorska, Karolina and Nicholas Wright, "Europeanization and the Common Foreign and Security Policy”, in The Europeanization of European Politics, eds. Charlotte Bretherton and Michael Mannin (New York: Palgrave Macmillan 2013): 151-62

Pomorska, Karolina, “The Impact of Enlargement: Europeanization of Polish Foreign Policy? Tracking Adaptation and Change in the Polish Ministry of Foreign Affairs”, The Hague Journal of Diplomacy 2 (2007): 25-51

Pomorska, Karolina, "Poland: Learning to Play the Brussels Game”, in National and European Foreign Policies: Towards Europeanization?, eds. Reuben Wong and Christopher Hill (New York: Routledge 2011): 167-88

Schimmelfennig, Frank, “The Community Trap: Liberal Norms, Rhetorical Action, and the Eastern Enlargement of the European Union”, International Organization 55 (2001): 47-80

Schimmelfennig, Fank, “Entrapped Again: The Way to EU Membership Negotiations with Turkey”, International Politics 46 (2009): 413-31 
Schimmelfennig, Frank, and Ulrich Sedelmeier, "Governance by Conditionality: EU Rule Transfer to the Candidate Countries of Central and Eastern Europe”, Journal of European Public Policy 11 (2004): 661-79

Schimmelfennig, Frank and Wolfgang Wagner, "Preface: External Governance in the European Union”, Journal of European Public Policy 11 (2004): 657-60

Sedelmeier, Ulrich, “After Conditionality: Post-Accession Compliance with EU Law in East Central Europe”, Journal of European Public Policy 15 (2008): 806-25

Sedelmeier, Ulrich, "Europeanisation in New Member and Candidate States", Living Reviews in European Governance 6 (2011): 5-52

Smith, Michael, “Conforming to Europe: The Domestic Impact of EU Foreign Policy Cooperation”, Journal of European Public Policy 7 (2000): 613-31

Szymanski, Adam, “The Position of Polish Political Elites on Future EU Enlargement”, Journal of Communist Studies and Transition Politics 23 (2007): 548-60

Thomas, Daniel, "Explaining the Negotiation of EU Foreign Policy: Normative Institutionalism and Alternative Approaches”, International Politics 46 (2009): 339-57

Youngs, Richard, “'A Door Neither Closed Nor Open': EU Policy Towards Ukraine During and Since the Orange Revolution”, International Politics 46 (2009): 358-75

Youngs, Richard, "EU Policy on Ukraine During and Since the Orange Revolution: 'A Door Neither Closed Nor Open”, in Making EU Foreign Policy, ed. Daniel Thomas, (Houndsmills: Palgrave Macmillan 2011): 31-49

Verdun, Amy, "The Challenges of European Union: Where are we today, how did we get here, and what lies ahead?”, The European Union in the Wake of Eastern Enlargement, in eds. Amy Verdun and Osvaldo Croci (Manchester University Press 2005): 9-22

Wallace, Helen, "Europeanisation and Globalisation: Complementary or Contradictory Trends", New Political Economy 5 (2001): 369-82

Wong, Reuben, "The Europeanisation of Foreign Policy”, in International Relations and the European Union, eds. Christopher Hill and Michael Smith (Oxford: Oxford University Press 2005): 134-53

Wong, Reuben, The Europeanization of French Foreign Policy: France and the EU in East Asia, (New York: Palgrave Macmillan 2006)

Wong, Reuben “Foreign Policy”, in Europeanization: New Research Agendas, eds. Paolo Graziano and Maarten Vink (New York: Palgrave Macmillan 2007): 321-334 
Wong, Reuben and Christopher Hill, "Introduction”, in National and European Foreign Policies: Towards Europeanization?, eds. Reuben Wong and Christopher Hill (New York: Routledge 2011): 1-18

Zimmer, Christina, Gerald Schneider, and Michael Dobbins, "The Contested Council: Conflict Dimensions of an Intergovernmental EU Institution”, Political Studies 53 (2005): 403-22

Zubek, Radoslaw, "Complying with Transposition Commitments in Poland: Collective Dilemmas, Core Executive, and Legislative Outcomes”, West European Politics 28 (2005): 592619 
Correct citation: Dumka, Ivan F. 2013. “Europeanization in EU External Relations after the Eastward Enlargement: Complications and Bypasses to Greater Engagement with the Eastern ENP Countries.” Review of European and Russian Affairs 8 (1): 1-24.

Published by the Centre for European Studies at Carleton University, Ottawa, Canada. Available online at: $\underline{w w w . c a r l e t o n . c a / r e r a / ~}$

RERA is an electronic academic peer-reviewed journal that publishes graduate, post-graduate, and young scholarly works. Topics relate to the European Union, its Member States, the former Soviet Union, and Central and Eastern Europe. The journal is a joint project supported by the Canada-Europe Transatlantic Dialogue-a cross-Canada research network supported by the Social Sciences and Humanities Research Council of Canada (SSHRC) - along with the Institute of European, Russian and Eurasian Studies (Carleton University) and its associated research unit, the Centre for European Studies.

RERA aims to provide an accessible forum for research, to promote high standards of research and scholarship, and to foster communication among young scholars.

\section{Contact:}

Carleton University

The Centre for European Studies

1103 Dunton Tower

1125 Colonel By Drive

Ottawa,

ON K1S

5B6

Canada

Tel: +01 613 520-2600 ext. 1179; E-mail: rera-journal@carleton.ca

\section{Creative Commons License}

\section{(c) $($ i) (9)}

http://creativecommons.org/licenses/by-nc-nd/3.0/

This Working Paper is licensed under a Creative Commons Attribution-NonCommercial- No Derivs 3.0 Unported License (CC BY-NC-ND 3.0).

Articles appearing in this publication may be freely quoted and reproduced provided the source is acknowledged. No use of this publication may be made for resale or other commercial purposes.

ISSN: 1718-4835

(C) 2013 The Author(s) 